DOI: https://doi.org/10.30837/MMP.2021.025

\title{
INFORMATION SUPPORT OF SIMULATION OF VEHICLE FLOW DISTRIBUTION IN URBAN PROJECTS OF SUSTAINABLE DEVELOPMENT
}

\author{
Chumachenko I., Davidich N., Galkin A.
}

Modeling vehicle flows is impossible without the introduction of IT. The study is aimed at developing models for the choice of routes, considering the individual characteristics of drivers, which are determined by the type of nervous system. On the basis of the analysis, the factors influencing the choice of the route by the drivers were identified. To fix the values of the obtained factors, a survey was carried out using a specially developed questionnaire. The type of the driver's nervous system was determined using a typological questionnaire. On the basis of the data obtained during the survey of drivers of vehicles, models were developed for changing the proportion of correspondence carried out along alternative routes of movement when driving drivers with different types of nervous systems. Based on the results obtained, it is possible to model the transport network, rationalize the development and planning of traffic flows, which are possible through the introduction of information technologies.

\section{INTRODUCTION}

The effective development of modern society is inextricably linked with the development of computer and information technologies [1]. IT that can be used in everyday design activities help to solve the problem of projecting the most adequate information systems [2]. The general principles of construction and operation of transport systems are analyzed through the prism of IT implemented in them. Successful creation and operation of transport system development projects can only be accomplished by the consistent implementation of the principles of constructing a program-targeted management mechanism, which makes it possible to refine the management methods in the transport development system in a new way [1]. Improving the quality of transportation services for urban residents is impossible without the creation of a management system with adaptive properties, which implies the implementation of the principle of compliance of supply with the needs of transport services, taking into account the external and internal conditions of 
functioning of the city transport system [2]. This corresponds to the directions of development of Smart infrastructure of cities. The pace of development of modern cities, the steady growth of urban freight transport have exacerbated a number of problems, such as the creation of a rational road organization system, road quality assurance and environmental protection. At present, the growth rates of freight transport are far ahead of the growth rates of new construction and reconstruction of existing transport highways in cities. As a result, there is a need to address traffic management issues to ensure the safety of road users, reduce load on the road network, and improve the environmental situation [3]. The functioning of the transport system can be improved by rationally distributing freight flows across sections of the city's road network [4]. System management, efficient organization of traffic flows, optimal planning of urban industrial Smart infrastructure and identification of possible scenarios for its development are required to manage the transport system and make optimal decisions in the field of transport planning [5]. The city's transport model, which is used to support managerial decision-making in strategic transportation planning, is an optimal tool for quantifying the proposed transport network development options, comparing them further, and making reasonable conclusions about the feasibility of investing in urban industrial infrastructure development projects. One of the most important links in the design of urban transport systems is to determine the patterns of formation of traffic flows and their distribution on sections of the street and road network. Transport flows are a special physical phenomenon that has its own patterns and characteristics that cannot be applied to each car individually.

The state of flows is generated by the collective movement of drivers of transport units meeting their travel needs [6]. The goal of the driver may be to minimize travel-related losses, such as driving time, energy costs, and maximize safety with the slightest deviation from comfortable conditions. It should also take into account the possibility of traveling on several routes [7]. For each route of the alternative variants, the driver generates a utility function. Its researchers represent a linear dependence on the characteristics of alternatives [8]. The driver evaluates all 
variants, taking into account many random influences. The current time resource, health state, weather conditions, etc. are taken into account. As a consequence, the driver makes decisions independently of other road users [9]. In addition, the researchers find that the driver, most often, associates the degree of danger of a situation with the degree of complexity of driving and decision-making in it. To some extent, a criterion is associated with safety, which gives an assessment of the driver's efforts to drive. It may be necessary to consider the psychophysiological features of drivers in this situation as well [10]. Psychophysiological characteristics of drivers, along with the purpose of the trip, age and skill of driving, determine the collective behavior of traffic participants, which underlies the formation and distribution of traffic flows [11]. The individual qualities of the driver play an important role in the parameters of the movement of vehicles [12]. According to the researchers, this factor is currently under-researched. Scientists propose to combine the individual characteristics of people with the same properties of the central nervous system. In their view, this grouping will reduce the loss of individual features compared to the use of total characteristics. These emotional properties and qualities of temperament are considered by researchers to be common indicators of a tendency to danger. According to scientists, the properties of the nervous processes form certain combinations that determine the type of nervous system or the type of higher nervous activity [13]. It consists of a set of basic properties of the nervous system that is characteristic for certain individuals - the strength, balance, and mobility of the processes of excitation and inhibition. These properties of the nervous system cause the adaptation of the animal organism to the surrounding conditions, i.e. the perfect interaction of the organism as a system with the external environment, ensure the existence of the organism flows [11]. The researchers highlight the four most pronounced types of nervous system, and their connection with temperament. Researchers define four classic types of temperament, depending on the basic characteristics of the nervous system: strong, balanced, lively - sanguine; strong, balanced, inert - phlegmatic; strong, unbalanced type with predominance of excitation - choleric; weak type - melancholic. They understand the type of 
nervous system as congenital, weakly affected by changes in the environment and upbringing. In their view, the properties of the nervous system form the physiological basis of temperament, which is a mental manifestation of the general type of nervous system. As researchers have proven, the strength and stability of the nervous system determine the behavior and actions of the driver [12-17]. Therefore, the choice of the route of movement depends on the type of nervous system and his temperament. As a result, the development of urban industrial Smart Infrastructure should take these features into account when choosing drivers' routes.

\section{THE PURPOSE AND METHODOLOGY OF THE STUDY}

The purpose of the study was to develop and evaluate statistical models that describe the change in the proportion of freight transport correspondence that is implemented along the route with the relevant parameters during the process of freight transportation in an urban environment. The studies were conducted during the following stages:

1) conducting a full-scale survey to determine the age and temperament of the drivers, as well as their chosen route of movement between the origin and destination points;

2) determination of routes parameters chosen by drivers for movement between the origin and destination points;

3) statistical processing of the received data for determining the connection of change of the share of freight transport correspondence, which is realized on the route of movement, from the parameters of the route.

Determining patterns of choice of the movement route by drivers should be based on information about the routes that drivers choose when moving between the origin and destination points. To solve this problem, a corresponding questionnaire was developed, which is presented in fig. 1. 
Your age

Your driver's experience

Enter the make of your car

Name of the accountant

Date of the survey

Type of nervous system

Specify the route you will take from the point of origin and destination

Fig. 1. Questionnaire survey for drivers on driving directions

The questionnaire survey was based on the ability of drivers to act as experts and was carried out at the Kharkiv transport companies performing cargo transportation. At the beginning of the survey, the questionnaire included the driver's age, driving experience and the car make. The type of nervous system was also determined for taking into account the individual characteristics of the respondents using a typological questionnaire [17]. The survey involved 400 drivers, of whom 259 had a sanguine temperament, 60 had a phlegmatic temperament, 47 had a melancholic temperament, and 34 had a sanguine temperament. In the second stage, the drivers were asked to choose the traffic routes they chose to drive along the city's road network between the different areas of origin and destination. Thus, surveys were conducted for thirty sets of points of origin and destination that had different locations in the Kharkiv city [18]. An example of the routes obtained is given in Table 1. For the defined routes, surveys of its parameters and traffic conditions were conducted using previously proposed methods [18]. Test results examples for drivers with "choleric" type of nervous system are shown in Table 2. Similarly, data were generated from the results of the survey for drivers with other types of nervous system.

Thus, after processing the survey results, the data necessary to determine the patterns of choice of traffic routes by the freight transport drivers were obtained. After determining the initial data for the simulation, models were developed for 
changing the proportion of transport correspondence, which is implemented on alternative traffic routes, while controlling drivers with different types of nervous system.

Table 1

\section{Driving directions chosen by drivers}

\begin{tabular}{|c|c|c|}
\hline $\begin{array}{l}\text { Origin- } \\
\text { destination } \\
\text { points }\end{array}$ & $\begin{array}{l}\text { Route } \\
\text { number }\end{array}$ & Route \\
\hline \multirow{6}{*}{$\begin{array}{l}\text { Serhiia } \\
\text { Hritsevtsa str. } \\
\text { - Liudviha } \\
\text { Svobody av. }\end{array}$} & 1.1 & $\begin{array}{l}\text { Serhiia Hritsevtsa str. - Moskovskyi av.- Pavlivska square - } \\
\text { Klochkivska str. - Nauky av. - Liudviha Svobody av. }\end{array}$ \\
\hline & 1.2 & $\begin{array}{l}\text { Serhiia Hritsevtsa str. - Moskovskyi av.- Traktorobudivnykiv av. - } \\
\text { Krasnodarska av. - Khalturina str.- Saltivske highway - } \\
\text { Semyhradska str. - Vesnina downhill - Sumska str. - Derevianko } \\
\text { str. - Askharova str. - Liudviha Svobody av. }\end{array}$ \\
\hline & 1.3 & Serhiia Hritsevtsa str.- Kiltseva road - Liudviha Svobody av. \\
\hline & 1.4 & $\begin{array}{l}\text { Serhiia Hritsevtsa str. - Moskovskyi av.- Armianskyi av.- } \\
\text { Konstytutsii square - Sumska str. - Derevianko str.- Akhsarova str. } \\
\text { - Liudviha Svobody av. }\end{array}$ \\
\hline & 1.5 & $\begin{array}{c}\text { Serhiia Hritsevtsa str. - Moskovskyi av.- Feiierbakha square - } \\
\text { Marshala Bazhanova str.- Pushkinska str. - Yaroslava Mudroho str. } \\
\text { - Sumska str.- Derevianko str.- Akhsarova str.- Liudviha Svobody } \\
\text { av. }\end{array}$ \\
\hline & 1.6 & $\begin{array}{l}\text { Serhiia Hritsevtsa str.- Moskovskyi av.- Akademika Pavlova str.- } \\
\text { Semihradska str.- Vesnina downhill - Sumska str. - Derevianko } \\
\text { str.- Askharova str.- Liudviha Svobody av. }\end{array}$ \\
\hline \multirow{3}{*}{$\begin{array}{l}\text { Druzhby } \\
\text { Narodiv str.- } \\
\text { Marshala } \\
\text { Konieva str. }\end{array}$} & 2.1 & $\begin{array}{c}\text { Druzhby Narodiv str.- Lesia Serdiuka str. - Akademika Pavlova } \\
\text { str.- Heroiv pratsi str. - Shevchenko str. - Pavlivska square - } \\
\text { Kontorska str.- Marshala Konieva str. }\end{array}$ \\
\hline & 2.2 & $\begin{array}{c}\text { Druzhby Narodiv str.- Komandorma Korka str. - Akademika } \\
\text { Pavlova str. - Moskovskyi av. - Pavlivska square - Kontorska str. - } \\
\text { Marshala Konieva str. }\end{array}$ \\
\hline & 2.3 & $\begin{array}{l}\text { Druzhby Narodiv str. - Lesia Serdiuka str. - Akademika Pavlova } \\
\text { str.- Heroiv pratsi str. - Shevchenko str. - Belhorodskyi downhill - } \\
\text { Darvina str.- Pushkinska str.- Skrypnyka str. - Rymarska str.- } \\
\text { Klochkivska str.- Kontorska str. - Marshala Konieva str. }\end{array}$ \\
\hline
\end{tabular}


Table 2

The surveys results of the routes of movement of the drivers with a "choleric" type of nervous system

\begin{tabular}{|c|c|c|c|c|c|c|c|c|c|c|c|}
\hline 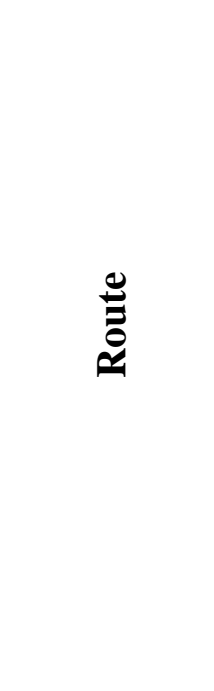 & 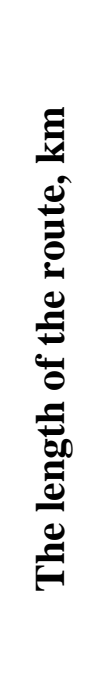 & 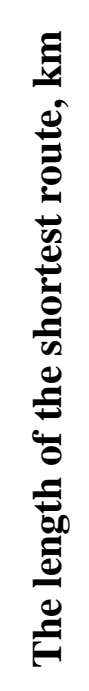 & 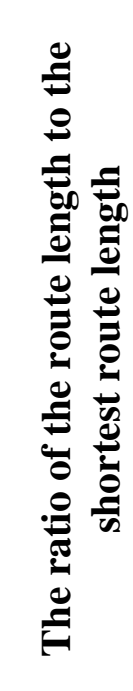 & 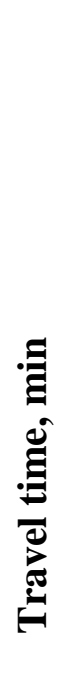 & 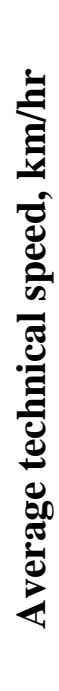 & 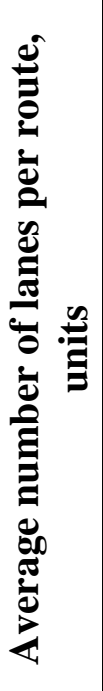 & 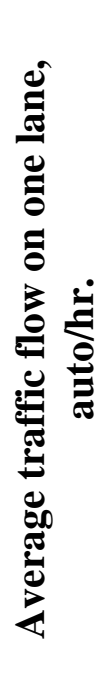 & 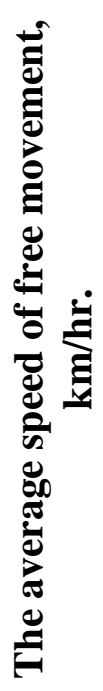 & 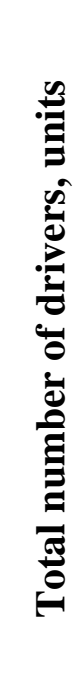 & 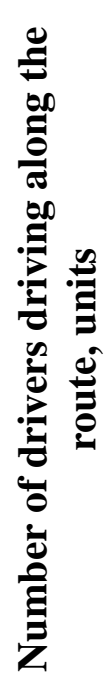 & 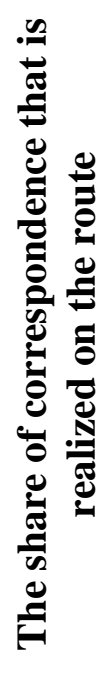 \\
\hline \multirow{6}{*}{$\begin{array}{c}\text { Serhiia } \\
\text { Hritsevtsa } \\
\text { boul. - } \\
\text { Liudviha } \\
\text { Svobody av. }\end{array}$} & 43 & \multirow{6}{*}{24} & 1,79 & 63 & 41 & 2 & 315 & 47 & \multirow{6}{*}{34} & 1 & 0,029 \\
\hline & 24 & & 1,00 & 53 & 27 & 2,5 & 300 & 50 & & 10 & 0,294 \\
\hline & 36,5 & & 1,52 & 56 & 39 & 2,5 & 310 & 48 & & 14 & 0,441 \\
\hline & 25,9 & & 1,08 & 48 & 32 & 2 & 354 & 52 & & 1 & 0,029 \\
\hline & 25,5 & & 1,06 & 58 & 26 & 2 & 401 & 50 & & 2 & 0,059 \\
\hline & 32 & & 1,33 & 55 & 35 & 2 & 355 & 55 & & 6 & 0,176 \\
\hline \multirow{3}{*}{$\begin{array}{c}\text { Druzhby } \\
\text { Narodiv } \\
\text { str.- } \\
\text { Marshala }\end{array}$} & 19,2 & \multirow{4}{*}{14,5} & 1,32 & 43 & 27 & 2 & 548 & 47 & \multirow{4}{*}{34} & 13 & 0,382 \\
\hline & 14,5 & & 1,00 & 47 & 19 & 2 & 173 & 53 & & 11 & $\begin{array}{c}0,324 \\
3\end{array}$ \\
\hline & & & & & & & & & & & \\
\hline $\begin{array}{c}\text { Konieva } \\
\text { str. }\end{array}$ & 19,6 & & 1,35 & 45 & 26 & 2,5 & 225 & 51 & & 9 & 0,265 \\
\hline
\end{tabular}

\section{MODELS OF CHANGE OF TRANSPORT CORRESPONDENCE SHARE} REALIZED ON ALTERNATIVE ROUTES OF MOVEMENT, AT

\section{MANAGEMENT OF DRIVERS WITH DIFFERENT TYPES OF NERVOUS SYSTEM}

Based on the correlation and regression analysis methods, the problem of mathematical description of the change in the freight transport share of correspondence, which is realized along the route of movement, was carried out. The 
regression coefficients were calculated using the least squares method [19]. The calculations results of the parameters of the model change in the proportion of correspondence, which is realized on alternative routes of movement, when driving with a "choleric" type of nervous system, are given in table. 3 . The model is as follows:

$$
\Delta K^{\mathrm{xol}}=0,47 \cdot V_{m} / V_{k r a t}-0,18 \cdot L_{m} / L_{k r a t},
$$

where $V_{m} / V_{\text {krat }}$ - ratio of speed of movement on a route to speed of movement on the shortest route; $L_{m} / L_{\text {krat }}$ - the ratio of the route length to the shortest route length.

Table 3

\section{Characteristics of the model change in the proportion of correspondence} realized on alternative traffic routes when driving with a "choleric" type of nervous system

\begin{tabular}{|c|c|c|c|c|c|c|c|c|}
\hline \multirow[t]{2}{*}{ Factors } & \multirow[t]{2}{*}{ Symbol } & \multirow{2}{*}{ 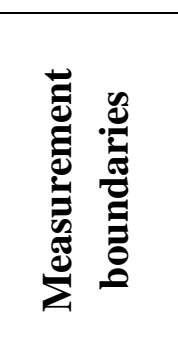 } & \multirow{2}{*}{ ن⿺辶ِّ } & \multirow{2}{*}{ 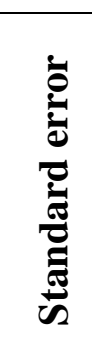 } & \multicolumn{2}{|c|}{$\begin{array}{l}\text { Student's } \\
\text { t-test }\end{array}$} & \multicolumn{2}{|c|}{$\begin{array}{c}\text { Confidence } \\
\text { intervals of } \\
\text { model } \\
\text { coefficients }\end{array}$} \\
\hline & & & & & Actual & $\begin{array}{l}\text { Calcu- } \\
\text { lated }\end{array}$ & $\begin{array}{l}\text { Lower } \\
\text { bound }\end{array}$ & $\begin{array}{l}\text { Upper } \\
\text { bound }\end{array}$ \\
\hline $\begin{array}{l}\text { The ratio of the } \\
\text { speed of the route to } \\
\text { the speed of the } \\
\text { shortest route }\end{array}$ & $V_{m} / V_{\text {krat }}$ & $0,68-1,75$ & 0.47 & 0.22 & 2.17 & 2.02 & 0.02 & 1.17 \\
\hline $\begin{array}{l}\text { The ratio of the } \\
\text { route length to the } \\
\text { shortest route } \\
\text { length }\end{array}$ & $L_{m} / L_{k r a t}$ & $1-1,86$ & -0.18 & 0.21 & 2.83 & 2.02 & -0.35 & -0.01 \\
\hline
\end{tabular}

Of all the factors studied, only four were found to be significant, forming two relationships. This is evidenced by the calculated values of Student's t-test, which is greater than the table value, as well as the absence of zero in the confidence interval of each factor of the model.

After the development of the regression model of changes in the proportion of correspondence that is realized on alternative traffic routes, when driving with a 
"choleric" type of nervous system, its statistical evaluation was conducted. The multiple correlation coefficient of the model was 0.99, and the average approximation error was $10.6 \%$. The results obtained allowed to draw a conclusion about the admissibility of using the obtained model for modeling traffic flows in an urban environment taking into account the human factor.

The calculations results of the parameters of the model change in the proportion of correspondence, which is realized on alternative routes of movement, when driving with a "sanguine" type of nervous system, are given in table 4.

Table 4

Characteristics of the model change in the proportion of correspondence realized on alternative traffic routes when driving with a "sanguine" type of nervous system

\begin{tabular}{|c|c|c|c|c|c|c|c|c|}
\hline \multirow[t]{2}{*}{ Factors } & \multirow[t]{2}{*}{ Symbol } & \multirow{2}{*}{ 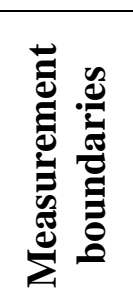 } & \multirow{2}{*}{ نัّ } & \multirow{2}{*}{ 薦 } & \multicolumn{2}{|c|}{$\begin{array}{l}\text { Student's } \\
\text { t-test }\end{array}$} & \multicolumn{2}{|c|}{$\begin{array}{c}\text { Confidence } \\
\text { intervals of } \\
\text { model } \\
\text { coefficients }\end{array}$} \\
\hline & & & & & Actual & $\begin{array}{l}\text { Calcu- } \\
\text { lated }\end{array}$ & $\begin{array}{l}\text { Lower } \\
\text { bound }\end{array}$ & $\begin{array}{l}\text { Upper } \\
\text { bound }\end{array}$ \\
\hline $\begin{array}{l}\text { The ratio of the } \\
\text { speed of the } \\
\text { route to the } \\
\text { speed of the } \\
\text { shortest route }\end{array}$ & $V_{m} / V_{\text {krat }}$ & $\begin{array}{l}0,68- \\
1,75\end{array}$ & 0.23 & 0.12 & 2.89 & 2.04 & 0.05 & 0.50 \\
\hline $\begin{array}{l}\text { The ratio of the } \\
\text { route length to } \\
\text { the shortest } \\
\text { route length }\end{array}$ & $L_{m} / L_{\text {krat }}$ & $1-1,86$ & -0.07 & 0.11 & 2.64 & 2.04 & -0.13 & -0.01 \\
\hline
\end{tabular}

The model is as follows:

$$
\Delta K^{\text {sang }}=0,23 \cdot V_{m} / V_{k r a t}-0,07 \cdot L_{m} / L_{k r a t} .
$$

Of all the factors studied, only four were found to be significant, forming two relationships. This is evidenced by the calculated values of Student's t-test, which is greater than the table value, as well as the absence of zero in the confidence interval of each factor of the model. 
After the development of the regression model of changes in the proportion of correspondence, which is realized on alternative routes of movement, when driving with a "sanguine" type of nervous system, its statistical evaluation was conducted. The multiple correlation coefficient of the model was 0.99 , and the average approximation error was $9.28 \%$. The results of calculations of parameters of model change of a correspondence share realized on alternative routes of movement, at management of the driver with a "phlegmatic" type of nervous system, are given in table 5.

Table 5

Characteristics of the model change in the proportion of correspondence realized on alternative traffic routes when driving with a "phlegmatic" type of nervous system

\begin{tabular}{|c|c|c|c|c|c|c|c|c|}
\hline \multirow[t]{2}{*}{ Factors } & \multirow[t]{2}{*}{ Symbol } & \multirow{2}{*}{ 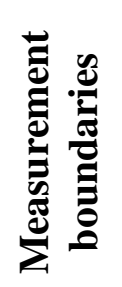 } & \multirow{2}{*}{ 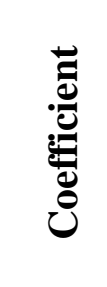 } & \multirow{2}{*}{ 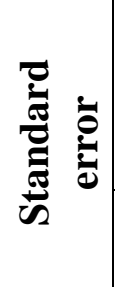 } & \multicolumn{2}{|c|}{$\begin{array}{c}\text { Student's } \\
\text { t-test }\end{array}$} & \multicolumn{2}{|c|}{$\begin{array}{c}\text { Confidence } \\
\text { intervals of } \\
\text { model } \\
\text { coefficients } \\
\end{array}$} \\
\hline & & & & & Actual & $\begin{array}{c}\text { Calcu- } \\
\text { lated }\end{array}$ & $\begin{array}{l}\text { Lower } \\
\text { bound }\end{array}$ & $\begin{array}{l}\text { Upper } \\
\text { bound }\end{array}$ \\
\hline $\begin{array}{l}\text { The ratio of the } \\
\text { speed of the route to } \\
\text { the speed of the } \\
\text { shortest route }\end{array}$ & $V_{m} / V_{k r a t}$ & $\begin{array}{c}0,68- \\
1,75\end{array}$ & 0.14 & 0.13 & 2.13 & 2.02 & 0.04 & 0.29 \\
\hline $\begin{array}{l}\text { The ratio of the } \\
\text { route length to the } \\
\text { shortest route } \\
\text { length }\end{array}$ & $L_{m} / L_{k r a t}$ & $1-1,86$ & -0.05 & 0.15 & 2.34 & 2.02 & -0.11 & -0.01 \\
\hline
\end{tabular}

The model is as follows:

$$
\Delta K^{\text {fleg }}=0,14 \cdot V_{m} / V_{\text {krat }}-0,05 \cdot L_{m} / L_{k r a t} .
$$

Of all the factors studied, only four were found to be significant, forming two relationships. This is evidenced by the calculated values of Student's t-test, which is greater than the table value, as well as the absence of zero in the confidence interval of each factor of the model.

After the development of the regression model of changes in the proportion of correspondence, which is realized on alternative routes of movement, when driving 
with a "melancholic" type of nervous system, its statistical evaluation was conducted. The multiple correlation coefficient of the model was 0.98 , and the average approximation error was $12.47 \%$. The results obtained allowed to draw a conclusion about the admissibility of using the obtained model for modeling of traffic flows in an urban environment taking into account the human factor. The results of calculations of the parameters of the model change in the proportion of correspondence, which is realized on alternative routes of movement, when driving with a "melancholic" type of nervous system, are given in table 6.

Table 6

Characteristics of the model change in the proportion of correspondence realized on alternative traffic routes when driving with a "melancholic" type of nervous system

\begin{tabular}{|c|c|c|c|c|c|c|c|c|}
\hline \multirow[t]{2}{*}{ Factors } & \multirow[t]{2}{*}{ Symbol } & \multirow{2}{*}{ 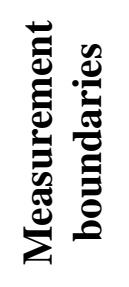 } & \multirow{2}{*}{ ن̃ } & \multirow{2}{*}{ 冚 } & \multicolumn{2}{|c|}{$\begin{array}{c}\text { Student's } \\
\text { t-test }\end{array}$} & \multicolumn{2}{|c|}{$\begin{array}{c}\text { Confidence } \\
\text { intervals of } \\
\text { model } \\
\text { coefficients }\end{array}$} \\
\hline & & & & & Actual & $\begin{array}{l}\text { Calcu- } \\
\text { lated }\end{array}$ & $\begin{array}{l}\text { Lower } \\
\text { bound }\end{array}$ & $\begin{array}{l}\text { Upper } \\
\text { bound }\end{array}$ \\
\hline $\begin{array}{l}\text { The ratio of the } \\
\text { speed of the route } \\
\text { to the speed of the } \\
\text { shortest route }\end{array}$ & $V_{m} / V_{\text {krat }}$ & $\begin{array}{c}0,68- \\
1,75\end{array}$ & 0.48 & 0.18 & 2.62 & 2.02 & 0.021 & 0.65 \\
\hline $\begin{array}{l}\text { The ratio of the } \\
\text { route length to the } \\
\text { shortest route } \\
\text { length }\end{array}$ & $L_{m} / L_{k r a t}$ & $1-1,86$ & -0.02 & 0.14 & 2.14 & 2.02 & -0.05 & -0.001 \\
\hline
\end{tabular}

The model is as follows:

$$
\Delta K^{\text {melan }}=0,48 \cdot V_{m} / V_{k r a t}-0,02 \cdot L_{m} / L_{k r a t} .
$$

Of all the factors studied, only four were found to be significant, forming two relationships. This is evidenced by the calculated values of Student's t-test, which is greater than the table value, as well as the absence of zero in the confidence interval of each factor of the model. 
After the development of the regression model changes in the proportion of correspondence, which is realized on alternative routes of movement, when driving with a "melancholic" type of nervous system, its statistical evaluation was conducted. The multiple correlation coefficient of the model was 0.98 , and the average approximation error was $9.3 \%$. The obtained results allowed to draw a conclusion about the admissibility of using the obtained model for modeling freight transport traffic flows in an urban environment taking into account the human factor.

\section{ANAL YSIS OF THE CHANGE IN THE PROPORTION OF CORRESPONDENCE, WHICH IS REALIZED ON ALTERNATIVE ROUTES OF MOVEMENT, WHEN DRIVING WITH DIFFERENT TYPES OF NERVOUS SYSTEM}

To analyze the common influence of factors on the proportion of traffic correspondence, which is implemented on alternative routes of traffic, when driving with different types of nervous system, a comparison of changes in the correspondence proportion depending on the parameters of the route was made. Fig. 2-3 show the dependencies of the change in the proportion of transport correspondence, which is realized on alternative traffic routes, when driving with different types of nervous system.

Analysis of fig. 2-3 showed that the highest proportion of correspondence is in drivers with melancholic type of nervous system. Researchers have determined that a melancholic is a person with a weak nervous system, his nervous processes are unbalanced, can be mobile or inert. He is prone to fluctuations, can not make decision for a long time, as it is very difficult for him to choose any of the possible options. He adapts badly to new living and working conditions, often retreats to difficulties and does not even try to overcome them. Drivers with the sanguine type of nervous system are constantly in doubt, practically do not perform any maneuvers on the road and are afraid of neighboring cars on the road. This determines the high value of the proportion of correspondence that is realized on alternative routes of travel, depending on the ratio of the length of the route to the shortest route length. Drivers 
with the melancholic type of nervous system choose the traffic routes with the least number of cars and practically does not change it. Analyzing Figure 3, it can be seen that the value of the share of correspondence is increasing with the value of the ratio of speed on the route to the speed on the shortest route for the same reasons.

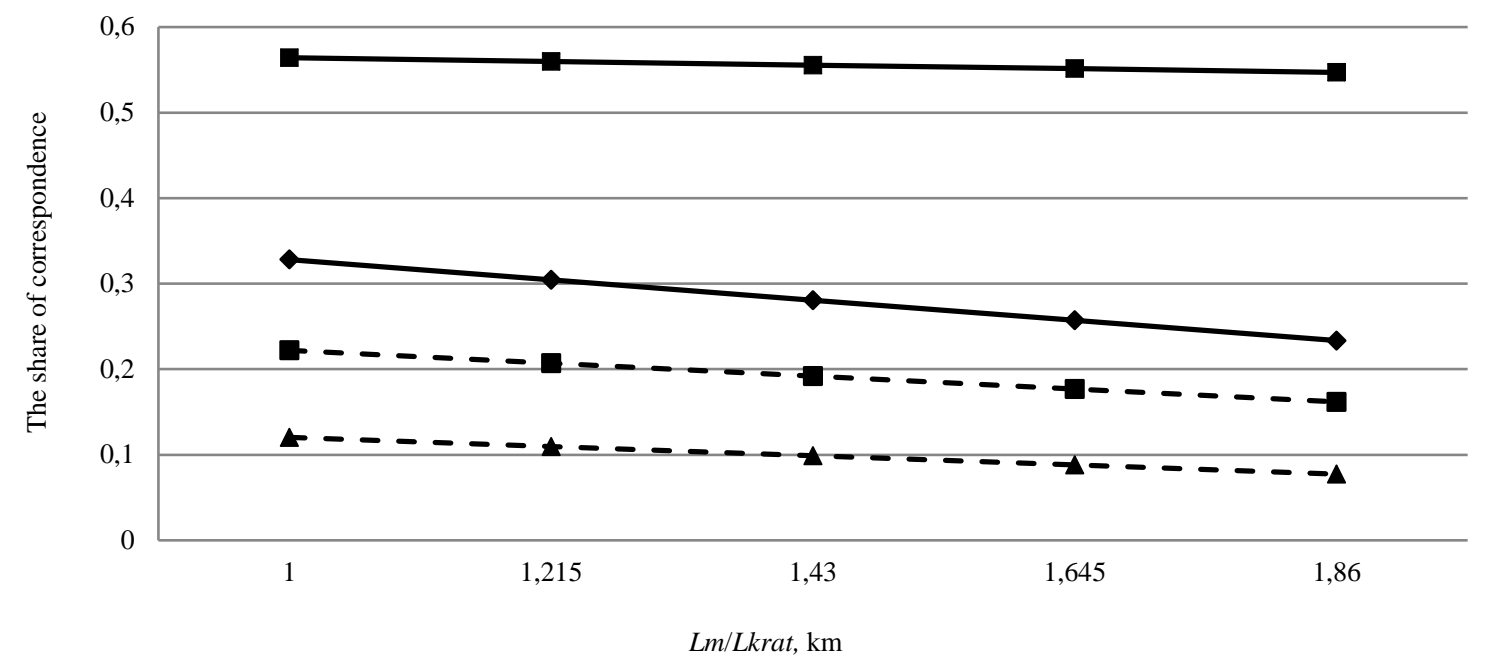

Fig. 2. The schedule of change of the correspondence share realized by alternative movement routes, at management of drivers with different type of nervous system depending on the ratio of the length of the route to the length of the shortest route:

$\rightarrow-$ - melancholic; $\rightarrow \longrightarrow$ - choleric; $\cdot-\mathbf{-}$ - sanguine; $\cdot \mathbf{A}-$ - phlegmatic.

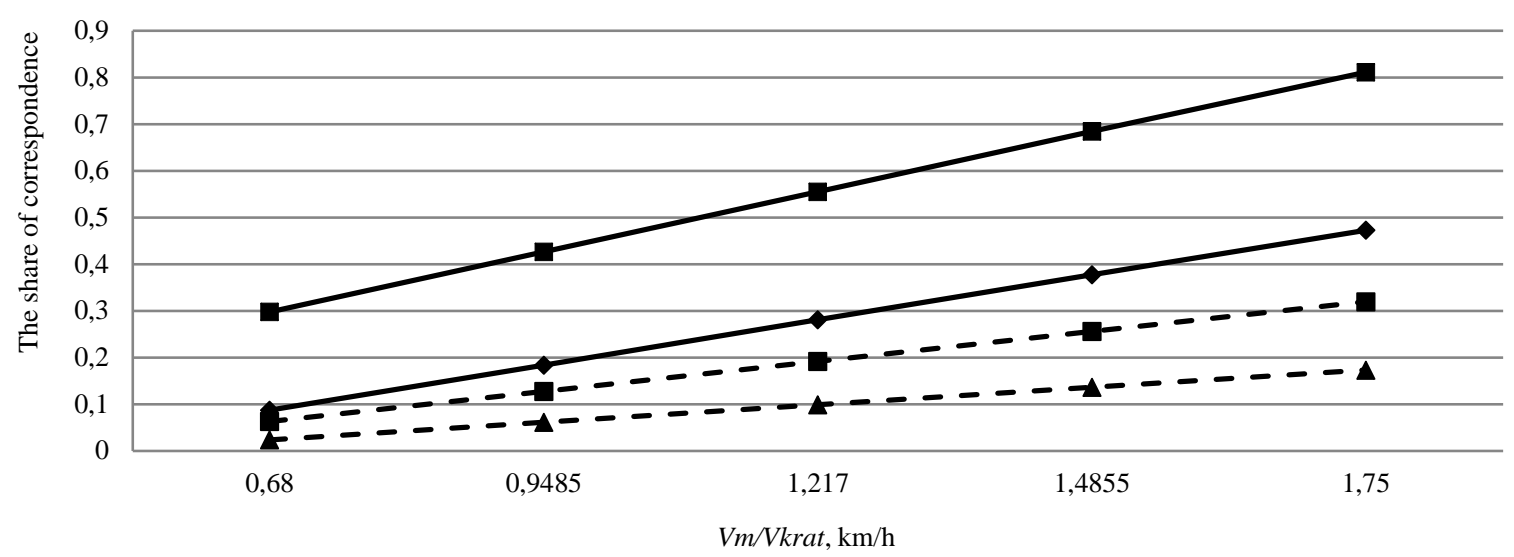

Fig. 3. The schedule of change of the correspondence share realized by alternative movement routes, at management of drivers with different type of nervous system depending on the relation of speed of movement on a route to speed of movement on the shortest route:

$\rightarrow-$ - melancholic; $\rightarrow-$ - choleric; $\cdot--$ - sanguine; $-\mathbf{A}-$ - phlegmatic. 
Less important is the proportion of correspondence in drivers with the choleric type of nervous system. Choleric as well as melancholic are emotionally unstable people, prone to stormy outward expression of their own feelings. Researchers determine that choleric is always an impulsive and nervous person, his actions are often dictated by emotions. Usually choleric is able to work hard, but quickly gets tired due to the increased excitability of the nervous system. Choleric is also a courageous and determined person, he is proactive and not inclined to go carefully on the road. Drivers with choleric type of nervous system are estimated to have a smaller but relatively high proportion of correspondence, compared to drivers with the melancholic type of nervous system, as they are also emotionally unstable, but confident drivers.

Even smaller is the proportion of correspondence among drivers with the sanguine type of nervous system. Sanguine people are mobile people who are characterized by a quick change of mood. They perform well in conditions of busy traffic on the roads, but are poorly resistant to a monotonous irritant. A lively urban movement is more suitable for them, rather than a boring suburban ride. They perfectly perform tasks that require high ingenuity. Therefore, drivers with sanguine type of nervous system have a low share of correspondence, because they do not "go from one extreme to another", but rather assess the traffic situation.

The smallest proportion of correspondence is in drivers with the phlegmatic type of nervous system, because it is usually a calm and slow person, not prone to constant change of emotions and to their extremely rapid manifestation. Phlegmatic have a balanced nature, it is difficult to get them out of balance. They are generally slow, so before making any decision, they prefer to think it over quietly - and only then act. Drivers with the phlegmatic type of nervous system are calm balanced drivers who prefer a quiet ride and live on the principle "more haste, more waste". 


\section{CONCLUSIONS}

The use of psychophysiological studies methods allowed us to assess the type of nervous system and driver's temperament. This made it possible for the first time to determine the degree of influence of the street and road network parameters on the choice of drivers with different nervous systems type of the traffic route when transporting goods in cities. In contrast to the existing approach to planning the parameters of the transport process, it is assumed that the type of nervous system of drivers, which influences the choice of the movement route, was taken into account when considering the organization of the freight transport movement. It was found that the parameters of traffic on different routes have a differentiated influence on the driving of different temperaments. As a result, it is advisable to plan the parameters of the freight traffic flow taking into account the type of driver's nervous system. The models presented show the value of the proportion of freight transport correspondence that will be implemented along the route with the appropriate parameters. Their use will allow to predict the load on the road network by trucks. As a result, there is an opportunity to assess the impact of industrial infrastructure on the state of the urban transport system. This can be one of the elements of smart cities infrastructure.

Such approach to the formation of freight traffic allowed to take into account the human factor and the parameters of the road network. However, it does not fully monitor the formation of freight flows. It only takes into account the type of driver's nervous system. In fact, the choice of the route is also influenced by the driver's age and qualifications. The measurement results allow the organizers of the transport process to identify possible routes for drivers with different types of nervous systems. Therefore, the models presented can be used for route design and vehicle planning, taking the human factor as a variable to increase the efficiency of the transportation process. 
The obtained models of change in the correspondence share of freight transport realized by alternative traffic routes, managed by drivers with different nervous system type, can be used in designing traffic routes in cities in which the parameters of the transport process and drivers are consistent with the range of changes of models factors. The diversity of the data range presented by the factors considered covers the real data of freight transportation in the Ukrainian cities. According to the analysis, the results presented can be applied in any city or transport system if the variation data is similar or included in the proposed model. In this case, the models must take into account specific city restrictions. The presented approach extends the knowledge gained in solving the problems of organizing the transport process and monitoring the formation of freight traffic flows in cities, and introduces new principles of urban development planning using Smart infrastructure technology.

\section{REFERENCES}

1. Ignatenko O. S., Ignatenko D. O., \& Tsymbal N. M. Methodical aspects of road transport development. Project management, System analysis and logistics, 2010, 17, 102-103.

2. Vinychenko V.S. Transport management system - Kharkiv: KHNMG, 2010, 44.

3. Kijewska, K., \& Iwan, S. Analysis of the functioning of urban deliveries in the city centre and its environmental impact based on Szczecin example. Transportation Research Procedia, 2016, 12, 739-749.

4. Semchenko N. O., \& Reshetnikov is a. B. Study of parameters of traffic groups of vehicles on the street-road network of the city. Municipal Economy cities: ZB. Sciences. Works. - Series: Technical Sciences and architecture, 2018, 7, 12-19.

5. Pashchenko Yu. Y., \& Dorogunsov S. I. Development and placement of transport and road complex of Ukraine. - Kyiv: Sciences. World, 2003, 467.

6. Davidich, N., Galkin, A., Sabadash, V., Chumachenko, I., Melenchuk, T., \& Davidich, Y. Projecting of Urban Transport Infrastructure Considering the Human Factor. Communications-Scientific letters of the University of Zilina, 2020, 22(1), 84-94. 
7. Grigorova, T. M., Davidich, Yu. O., Dolya, V. K. Development of distribution model of passenger transportation volumes among suburban transport modes. Eastern-European Journal of Enterprise Technologies, 2015, 3(3(75)), 10.

8. Prasolenko, O., Burko, D., Tolmachov, I., Gyulyev, N., Galkin, A., \& Lobashov, O. Creating safer routing for urban freight transportation. Transportation Research Procedia, 2019, 39, 417-427.

9. González-Hernández, B., Usami, D. S., Prasolenko, O., Burko, D., Galkin, A., Lobashov, O., \& Persia, L. The driver's visual perception research to analyze pedestrian safety at twilight. Transportation research procedia, 2020, 45, 827-834.

10. Galkin, A., Davidich, N., Melenchuk, T., Kush, Y., Davidich, Y., \& Lobashov, O. Modelling Truck's Transportation Speed on the Route Considering Driver's State. Transportation research procedia, 2018, 30, 207-215.

11. Grigorova, T. M., Davidich, Yu. O., Dolya, V. K. Development of the model of the change in the passenger transport fatigue when approaching stopping points of suburban bus routes. Eastern-European Journal of Enterprise Technologies, 2015, 2(3(74)), 4.

12. Lobanov, E. M. Proektirovanie dorog i organizatsiya dvizheniya s uchetom psihofiziologii voditelya. Moscow: Transport, 1980, 311.

13. Gyulyev, N., Voronko, V., Ostashevskiy, S., Ponkratov, D., Psol, S., \& Bugayov, I. Development of models for assessing a driver's failure-free operation in a transportation system under conditions of traffic congestion. Eastern-European Journal Of Enterprise Technologies, 2020, 1(3(103)), 24-38.

14. Afanasieva, I., \& Galkin, A. Assessing the information flows and established their effects on the results of driver’s activity. Archives of Transport, 2018, 45(1), 7-23.

15. Moiseeva O. Yu. Psychodynamic of the information of the novelty. Number 1. Psychodynamic temperament. - Vladivostok: Mor. Gos. Univ-T, 2002, 52.

16. Kapski, D., Kasyanik, V., Lobashov, O., Volynets, A., Kaptsevich, O., \& Galkin, A. Estimating the parameters of traffic flows on the basis of processing of localization data on the movement of vehicles. Communications-Scientific letters of the University of Zilina, 2-19, 21(2), 89-99.

17. Polishchuk I. A., \& Vidrenko A. E. Atlas for an experimental study of deviations in human mental activity. - Kiev, Zdorovya, 197, 124.

18. Khomyak Y. V. The organization of traffic - K.: Vishcha school, 1986, 271. 